\title{
Patronage Factors In Islamic Banks In Pakistan
}

\author{
Raja Muhammad Nauman Bisharat \\ Foundation University Rawalpindi Campus, New Lalazar, Rawalpindi Cantt. Pakistan.
}

\begin{abstract}
Islamic banking has been developing and expanding its network across Pakistan. The study aimed at evaluation of the selection criteria for Islamic banking in Pakistan. To get this aim, pragmatic research design was incorporated. More specifically, qualitative and quantitative study methods were used in the study to explore the selection criteria for Islamic banking in Pakistan. A close ended questionnaire was incorporated to collect data from a sample of 300 customers of Islamic banks in Pakistan. The sample generated $81 \%$ response rate. It was found that rate of return, Islamic teachings and bank's reputation influence behavior of customers towards Islamic banks. Specifically, it was found that bank's reputation, rate of return and Islamic teachings strongly influence the general behavior of customers towards Islamic banks. Finally, it has been recommended that marketers of Islamic banks need to promote their good reputation to attract new customers. They can also promote the religious traditions in their advertisements to attract customers who are motivated to avail interest free banking services.
\end{abstract}

\section{Introduction}

Islamic banking is conducted by following the financial principles proposed by Islamic Shari'a that strictly prohibits involvement of interest in transactions (Haron and Azmi, 2008). Islam is one of the second largest religions followed in the world after Christianity. Almost 1.2 billion people in the world have been following Islam. The Islamic Shari'a provides a comprehensive code of life for different fields of life including social, economical and legal problems. The basic idea behind Islamic Shari'a is to develop a balanced society where everyone has equal rights.

Over the last 50 years, one of the important developments is the emergence of Islamic banking in the Muslim world. The emergence of Islamic banking system has not only appeared a strong component of financial system in the Islamic world but also emerged a competitive financial system with the traditional banking system. Islamic banking started back in 1960s (Haron and Azmi, 2008). However, the disapproval of interest by Islamic Shari'a started when rules for financial matters were developed. The idea of implementing Islamic financial principles led the thinkers and practitioners to develop Islamic banking system that could serve the needs of Muslim population. Since the development of Islamic banking in the early 1960s, this banking system has continued to play a significant role in the global financial system. The Islamic banks have received attention across the world regardless of the distinction in Muslim and non Muslim countries (Balz 2007; Haron and Azmi, 2008; Farooq, Ahmad and Jamil, 2010). The Islamic banking system has evolved over the period and now it serves as a competent industry with the traditional banking system in the world. It has been reported that asset of Islamic banking are set to cross with the commercial banking assets over the last four years (World Islamic Banking Competitiveness Report, 2013). In 2013, the return on equity (ROE) for the top 20 Islamic banks was recorded equivalent to $12.6 \%$ as compared to that of conventional banking system of $15 \%$. In addition to this, Islamic banks serve more than 38 million customers globally (World Islamic Banking Competitiveness Report, 2013). At the same time, reports also revealed that leading Islamic banks double in size every 4 years. This suggests that the Islamic banking system has been expanding day by day. In this regard, this study has been conducted to highlight the specific factors that influence customers to adopt services of Islamic banking system.

The current study is going to make addition in the existing literature by elaborating and specifying factors influencing customers to select Islamic banking. Specially, this study has highlighted the selection criteria of customers towards Islamic banking system. The results of this particular study are going to assist the marketers and practitioners in the Islamic banks to develop appropriate services for customers. This study provides an enhanced understanding to practitioners in the Islamic banks of Pakistan that will enable them to develop appropriate services to attract customers and account holders.

\section{Originality of research}

This particular study has given an original contribution to the existing literature from marketing perspective regarding selection criteria towards Islamic banking system in the Pakistan. The findings of this study reflect back to survey conducted with the customers of Islamic banks in Pakistan. All the primary and secondary data have been appropriately acknowledged and referenced. 


\subsection{Objectives}

The main purpose of the study is to evaluate the selection criteria for Islamic banking in Pakistan. the objectives defined for the study include: 1) To identify differences between Islamic and conventional banking system, 2) To identify factors influencing adoption of Islamic banking system in Pakistan, 3) To identify factors that restrict customers to adopt Islamic banking system, and 4) To propose marketing implications of study to practitioners for attracting customers towards Islamic banks

\section{Literature Review}

The Islamic banking system operates on the basis of principles proposed by Islamic Shari'a that describes basic consumer behavior and economic system of a society (Erol et al., 2007). Not only does the Islamic banking system prohibits taking interest and conforms principles of Shari'a regarding several financial products, but also this system aims to contribute for the fulfillment of socioeconomic objectives of the society (Haron and Yamirudèng 2003; and Balz 2007). Several authors have demonstrated that Islamic banks perform same functions as other conventional banks, but at the same time Islamic banks operate differently (Balz, 2007; Erol et al., 2007; Farooq, Ahmad and Jamil, 2010). Firstly, the Islamic banking system represents a system that reflects risk sharing, equity sharing and stake sharing with customers. These principles suggest that an entrepreneur and investor will be sharing the outcomes of a project, either in the form of losses or profits in an equitable manner (Dusuki and Abdullah, 2007). For instance, in the case of profits, both entrepreneur and investor would share profits with each other in an agreed proportion. On the contrary, in case of losses, all the capital losses would be borne by the individual who provides capital whereas the entrepreneur would only borne the losses of time and labor put into a project (Farooq, Ahmad and Jamil, 2010). Consequently, fair distribution of wealth is achieved through this system that $\mathrm{s}$ the essence of Islamic financial principles. Secondly, the Islamic banking system is based on the Islamic law that directs that Islamic banks have to perform in ethical and moral terms of the Islamic law. Any unethical activity or immoral operation assisted by Islamic banks would result in derivation from the basic principles of Islamic banking. Thirdly, a just and fair social system is supported by the Islamic banking system. This system prohibits accumulation of wealth for no reason in the form of interest. In this regard, Islamic banking system prohibits gambling, interest and all other related activities that are regarded as haram under Islamic principles. The Islamic banking system aims to protect the benefits and interests of all parties who are involved in the economic activities and also promote the welfare of the whole society (Erol et al., 2007).

When it comes to customer perceptions towards Islamic banking system, a profound literature is available that cover contradictory results (Ahmad and Haron, 2002; and Farooq, Ahmad and Jamil, 2010 and Ahmad, 2007). Dusuki and Abdullah (2007) noted that customers mainly prefer Islamic banks because of their fair distribution of profits. In addition, they also suggest that adherence to the Islamic principles of finance is the main motivation for customers to adopt this banking system. Contrary to this, Ahmad and Haron (2002) and Farooq, Ahmad and Jamil (2010) have examined the perceptions of corporate customers towards Islamic banking system. They suggest that most of respondents noted that they use services of Islamic banks as Islam prohibits any association of individuals with the activities involving interest that is followed in the conventional banks. At the same time, they have also revealed that many corporate customers use Islamic banking system because of profit sharing idea as it is the true spirit of this banking system.

Abdjalil et al (2010) have indicated an important factor considered by customers for selecting Islamic banking system. This factor was the rate of return that is offered by Islamic banks. In the same vein, Abdjalil et al (2010) have also noted that there exists a positive relationship between importance of rate of return and income of customers. This suggests that higher rate of return offered by Islamic banks attract more customers. This factor was endorsed by several other authors (Dusuki and Abdullah, 2007; Al-Ajmi et al., 2009; Ahmad, et al., 2010).

Several studies reflect that many customers select Islamic banking services on the basis of religious grounds. This suggests that customers who give value to Islamic financial principles are more likely to use Islamic banking services. Hence, customers prefer Islamic banking system as it involves free interest services.

Besides above mentioned principles, literature has also pointed out some factors that are not related with religion or interest principle. For instance, Almossawi (2001) has suggested that younger customers are more likely to focus on the availability of parking, bank's reputation, friendliness of staff of banks and quality services of Islamic banks before selecting any bank.

Ta and Har (2000) studied bank selection criteria of customers in Singapore. They have identified that customers prefer multiple factors for selecting the banking services in any banking mode. In this regard, results of their study revealed that price is the major factor considered by customers for selecting banking services. These results are aligned to those of Lateh, Ismail and Ariffin (2009), Gait and Worthington (2008), Liang and Wang (2007, Abdjalil et al. (2010) and Becket et al. (2000). Contrary to these results, Haque et al. (2009) have 
studied the banking selection criteria of customers in the Malaysia. Their analysis confirms that there exists positive relationship about availability of banking services, quality of services, confidence with the banks and social perspective of banks. This study implies that customers give higher priority to factors such as reliability of banking services and quality of services for selecting any banking mode. Similar results were found in the studies conducted by Dusuki and Abdullah (2007), Kaynak and Harcar (2004), Bley, and Kuehn (2004), and Erol et al. (2007). In another study conducted by Okumuş (2005) it was found that customers are unlikely to use banking services if they do not get relevant risk protection from the banks on their deposits. Hence, it implies that customers will not invest in the risky activities of banks. Specifically, Okumuş (2005) has suggested that customers are unlikely to withdraw savings from banks if they do not get adequate risk protection of funds.

\section{Type of Research}

The study will be based on pragmatic research design that involves qualitative and quantitative research methods. Furthermore, both methods are integrated in the data collection process to develop and extract justified results. The qualitative methods have been used in the study to review the literature resources regarding Islamic banking. In this respect, prior studies from customer adoption view have been critically analyzed to extract specific factors that influence adoption of Islamic banks. On the other hand, the quantitative research methods have been used in the study to get empirical evidence of the extent to which specific factors influence adoption of internet banking system in Pakistan. The qualitative methods have assisted in quantifying the factors to identify tat which factor is highly preferred by customers as compared to other factors.

\subsection{Type of Data}

This study is based on pragmatic research methods that suggest using primary and secondary data. Both types of data have contributed towards achievement of research aims and objectives. The primary data has been used in the study to get empirical evidence of factors considered by customers in Pakistan for adopting services of Islamic banking system. On the other hand, secondary data has been included in the study to review prior articles regarding adoption of services of Islamic banks.

\subsection{Data Collection Method}

For collecting primary data, close ended questionnaire has been used. The close ended questionnaire has helped to derive quantitative data from customer population of Islamic banks in Pakistan. The questionnaire has been designed into two segments. The first part of questionnaire has aimed at collection of personal data from customer population. On the other hand, second part of questionnaire is aimed at the evaluation of selection criteria of customers for Islamic banks in Pakistan.

For collection of primary data, the target customer population has been personally contacted. In this way, self organized survey has been conducted. This survey has also assisted in attaining higher response rate as compared to online or mail survey.

\subsection{Sample and Population}

The target population of the study is composed of customers of Islamic banks in twin cities of Islamabad and Rawalpindi. By using convenience sampling technique, a sample of 300 customers of Islamic banks has been chosen. From different Islamic banks of twin cities of Islamabad and Rawalpindi, sample subjects have been chosen on the basis of accessibility of the researchers. In order to enhance diversity in sample, the participants are selected from different locations.

\section{Results and Analysis}

For this paper, a sample of 300 customers of Islamic banks was selected. In the sample, a response rate of $81 \%$ was achieved that was adequate for getting reliable results. The demographics of respondents were analyzed descriptively whereas the results of research model are analyzed statistically.

\subsection{Demographics Results}

The gender profile of respondents suggested that $66 \%$ respondents were males whereas $34 \%$ were females. The education profile of respondents may also affect the behavior of customers towards adoption of Islamic banks. Therefore, this question was asked. The survey results revealed that $15 \%$ respondents had below high school level education. There had been $32 \%$ respondents who were equipped with high school level education, and 30\% had Bachelor level education. Rest of the respondents was either Masters of above this. As far as the age of respondents was concerned, it was found that $25 \%$ respondents were up to 20 years of age. $45 \%$ respondents were in the age limit of 21-30 years whereas 15\% respondents were between 31-40 years of age. The rest of the respondents were above 40 years of age. 
When asked about bank accounts in the conventional banks, it was found that $41 \%$ respondents had their accounts in such banks. This suggests that it does not mean that having accounts in the Islamic banks would restrict customers to have accounts in the conventional banks.

\subsection{Descriptive results}

The descriptive results of research suggest that the banks result in adoption of Islamic banks in the Pakistan. For analyzing the factors influencing adoption of Islamic banks, standard deviation and averages have been calculated. Following is the representation of descriptive statistics of the results of survey:

\begin{tabular}{|l|l|l|l|l|l|}
\hline Descriptive Statistics & $\mathrm{N}$ & Minimum & Maximum & Mean & Std. Deviation \\
\hline & 243 & 4.00 & 15.00 & 7.8781 & 2.2334 \\
\hline Saving Behavior & 243 & 3.00 & 15.00 & 5.9893 & 3.012 \\
\hline Economic Conditions & 243 & 5.00 & 22.00 & 11.2356 & 3.653 \\
\hline Islamic Teachings & 243 & 6.00 & 24.00 & 13.6745 & 3.214 \\
\hline Profit & 243 & & & & \\
\hline Valid N (list wise) & &
\end{tabular}

\section{Table 1: Descriptive Analysis of Variables}

\subsection{Correlation}

For analyzing the variables in an effective manner and also to evaluate factors influencing adoption of Islamic banks, correlation has been found. The correlation analysis is effective to determine relationship between the variables of model. The following table represents the correlation analysis:

\begin{tabular}{|c|l|l|l|l|l|}
\hline \multicolumn{2}{|c|}{ Correlations } & $\begin{array}{l}\text { General } \\
\text { Behavior }\end{array}$ & $\begin{array}{l}\text { Bank's } \\
\text { Reputation }\end{array}$ & $\begin{array}{l}\text { Islamic } \\
\text { Teachings }\end{array}$ & $\begin{array}{l}\text { Rate of } \\
\text { Return }\end{array}$ \\
\hline \multirow{3}{*}{ General Behavior } & Pearson Correlation & 1 & $.798^{* *}$ & $.815^{* *}$ & $.455^{* *}$ \\
\cline { 2 - 6 } & Sig. (2-tailed) & & .000 & .000 & .000 \\
\cline { 2 - 6 } & $\mathrm{N}$ & 243 & 243 & 243 & 243 \\
\hline \multirow{3}{*}{$\begin{array}{c}\text { Bank's } \\
\text { Reputation }\end{array}$} & Pearson Correlation & $.793^{* *}$ & 1 & $.842^{* *}$ & $.587^{* *}$ \\
\cline { 2 - 6 } & Sig. (2-tailed) & .000 & & .000 & .000 \\
\cline { 2 - 6 } & $\mathrm{N}$ & 243 & 243 & 243 & 243 \\
\hline \multirow{3}{*}{$\begin{array}{l}\text { Islamic } \\
\text { Teachings }\end{array}$} & Pearson Correlation & $.854^{* *}$ & $.895^{* *}$ & 1 & $.696^{* *}$ \\
\cline { 2 - 6 } & Sig. (2-tailed) & .000 & .000 & 243 & .000 \\
\cline { 2 - 6 } & $\mathrm{N}$ & 243 & 243 & $.696^{* *}$ & 1 \\
\hline \multirow{3}{*}{ Rate of Return } & Pearson Correlation & $.458^{* *}$ & $.679^{* *}$ & .000 & \\
\cline { 2 - 6 } & Sig. (2-tailed) & .000 & .000 & 243 & \\
\cline { 2 - 6 } & $\mathrm{N}$ & 243 & 243 & & \\
\hline
\end{tabular}

Table 2: Correlation

The above table of correlation suggests that there exist a correlation between Islamic banking behavior and the variables of study. The results reveal that bank's reputation and Islamic teachings have high correlation with the general behavior of customers towards Islamic banks. This is evident through correlation value of 0.798 between bank's reputation and general behavior towards Islamic banks. The second variable is Islamic teachings that have high correlation value of 0.815 with the general behavior of customers towards Islamic banks. The rate of return has low correlation value of 0.455 with the general behavior of customers towards Islamic banks.

\subsection{Regression Analysis}

For determining the factors that highly influence adoption of Islamic banks in Pakistan, regression analysis has been conducted. The survey results were analyzed through SPSS software to determine the specific variable that has high association with the behavior towards Islamic banks. The following table represents a clear picture of regression analysis:

\begin{tabular}{|c|c|c|c|c|c|c|}
\hline \multicolumn{7}{|c|}{ Model Summary } \\
\hline Model & & $\mathrm{R}$ & R Square & Adjusted R Square & $\begin{array}{l}\text { Std. Error of the } \\
\text { Estimate }\end{array}$ & $\begin{array}{l}\text { Durbin- } \\
\text { Watson }\end{array}$ \\
\hline dimension & 1 & .0 .845 & .0793 & .723 & 1.2578 & 1.750 \\
\hline
\end{tabular}


b. Dependent Variable: General Behavior towards Islamic banks

Table 3: Model Summary

\begin{tabular}{|l|l|l|l|l|l|l|}
\hline ANOVA $^{\mathbf{b}}$ \\
\hline Model & Sum of Squares & df & Mean Square & F & Sig. $^{\text {a }}$ \\
\hline \multirow{3}{*}{1} & Regression & 697.932 & 4 & 239.30 & 145.632 & $.001^{\mathrm{a}}$ \\
\cline { 2 - 7 } & Residual & 286.465 & 176 & 1.708 & & \\
\cline { 2 - 7 } & Total & 984.397 & 180 & & & \\
\hline \multicolumn{7}{|l|}{ a. Predictors: (Constant), Rate of Return, Bank's reputation, Islamic Teachings } \\
\hline
\end{tabular}

Table 4: ANOVA

The results of ANOVA Test reveal that the model is statistically significant that analyzed the factors affecting adoption of Islamic banking behavior. The above model demonstrates that the significance level is less than 0.05 that is a sign of approval that there exists a relationship or association between adoption of Islamic banking and independent variables of the study. Furthermore, to get more evidence of the research objectives, Durbin Watson analysis has been conducted as below:

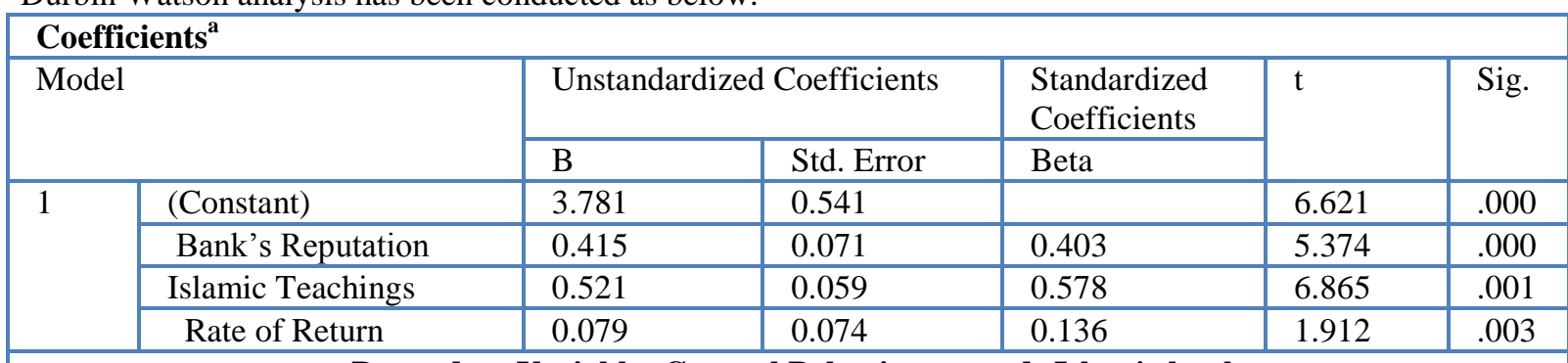

a. Dependent Variable: General Behavior towards Islamic banks

Table 5: Coefficients

The results of the above model reveal that rate of return, Islamic teachings and bank's reputation influence behavior of customers towards Islamic banks. It has been clear that significance level of all variables of study is below 0.05 that is adequate to make this model valid. Moreover, it is also clear that bank's reputation, rate of return and Islamic teachings strongly influence the general behavior of customers towards Islamic banks.

The results of this particular study validate the prior studies that reveal that customer behavior towards Islamic banks is influenced by several factors. For instance, prior studies have revealed that intentions to seek high rate of return influence customers to pursue services of Islamic banks (Farooq, Ahmad and Jamil, 2010). On the other hand, results of this study also align with the findings of Al-Ajmi et al (2009) who suggest that religious motivations of customers are the major factors that influence them to adopt Islamic banking services.

\section{Conclusion}

This study was focused on the evaluation of factors that influence customers to adopt Islamic banking in Pakistan. Descriptive and statistical analysis was made to evaluate the objectives of the research paper. $81 \%$ response rate was achieved in the survey that was conducted with the customers of Islamic banks in Pakistan. Through descriptive and statistical analysis, it has been concluded that customer behavior towards Islamic banks in Pakistan is influenced by multiple factors. The bank's reputation was found to be highly correlated with the dependent variable. On the other hand, Islamic teachings and rate of return offered by Islamic banks also influence customers to adopt Islamic banking services. In this way, it has been concluded that customers who think that Islamic banks are socially responsible and beneficial for the overall community should be availed. In addition, customers who are religious motivated to pursue interest free financial system are more likely to adopt services of Islamic banks. These results of study are aligned with the prior studies that have provided that religious motivations, socially responsible reputation of bank and fair rewards and returns offered by Islamic banks influence them to adopt this banking system (Al-Ajmi et al., 2009).

The results of this particular study can be further used by marketers of Islamic banks within Pakistan to attract customers. In the advertisements of bank's offerings, marketers of Islamic banks can attract customers. When customers will get more exposure and awareness about the social aspects of Islamic banks, they will adopt this banking system. In addition, this study also provides an effective understanding of the factors influencing customers to pursue Islamic banking system. 
The results of this particular study have several market implications. It has been recommended that the marketers of Islamic banks need to promote their good reputation to attract new customers. Moreover, another implication of this study is that the marketers of Islamic banks in Pakistan can promote the religious traditions in their advertisements to attract customers who are motivated to avail interest free banking services.

Although results of this study are valid and reliable to elaborate the understanding of factors influencing adoption of Islamic banking system in Pakistan, yet these results have lower generalizability. The main reason behind this was that small sample was used in this study. In this respect, future researchers have high scope to improve the results of this particular study. In this regard, future researchers can expand the scope of study by including a diverse and large sample from different cities of Pakistan so that results can be generalized to the entire Islamic banking system of the country.

\section{References}

[1]. Abdjalil, M., Yusoff, R. and Mahmud, R. (2010), Selection factors of customers towards Islamic dan conventional home financing products offered by Malayan banking Berhad: a case study in Johor, paper presented in the International Conference on Business and Economics, Andalas University, Padang, Indonesia.

[2]. Ahmad, A., Rehman, K., Saif, I. and Safwan, N. (2010), An empirical investigation of Islamic banking in Pakistan based on perception of service quality, African Journal of Business Management, Vol. 4 No. 6, pp. 1185-93.

[3]. Almossawi, M. (2001). Bank selection criteria employed by college students in Bahrain: An empirical analysis. International Journal of Bank Marketing. Vol. 19 (3): pp. 115-125.

[4]. Ahmad, M. (2007). Attitude of customers and bankers towards Islamic banking in Bangladesh. In Ali, S. S., and A. Ahmad (eds.), Islamic Banking and Finance: Fundamentals and Contemporary Issue: 169-195.

[5]. Ahmad, N. and Haron, S. (2002), Perceptions of Malaysian corporate customers towards Islamic banking products and services, International Journal of Islamic Financial Services, Vol. 3 No. 4, pp. 13-29.

[6]. Al-Ajmi, J., Hussain, H.A. and Al-Saleh, N. (2009), Clients of conventional and Islamic banks in Bahrain, how they choose which bank to patronise, International Journal of Social Economics, Vol. 36 No. 11, pp. 1086-112.

[7]. Becket, A., Hewer, P. and Howcroft, B. (2000), An exposition of consumer behavior in the financial services industry, International Journal of Bank Marketing, Vol. 18 No. 1, pp. 15-26.

[8]. Bley, J., and K. Kuehn. (2004). Conventional versus Islamic finance: Student knowledge and perception in the United Arab Emirates. International Journal of Islamic Financial Services. Vol. 5 (4). pp. 1-13.

[9]. Balz, K. (2007). Islamic finance for European moslem: The diversity management of Shari'abcompliant transactions. Chicago Journal of International Law. Vol. 1 (2): pp. 551.

[10]. Dusuki, A.W. and Abdullah, N.I. (2007), Why do Malaysian customers patronise Islamic banks? International Journal of Bank Marketing, Vol. 25 No. 3, pp. 142-60.

[11]. Erol, C., Kaynak, E. and El-Bdour, R. (2007), Conventional and Islamic banks: patronage behaviour of Jordanian customers, International Journal of Bank Marketing, Vol. 8 No. 4, pp. 25-35.

[12]. Farooq S., Ahmad G., and Jamil S. (2010). A Profile Analysis of the Customers of Islamic Banking in Peshawar, Pukhtunkhwa. International Journal of Business and Management. Vol. 5, No. 11. Pp. 106117

[13]. Grada, C., and White, E. N. (2003). The Panics of 1854 and 1857: A View from the Emigrant Industrial Savings Bank. Journal of Economic History, Vol. 63(1), pp. 213-240.

[14]. Gait, A. and Worthington, A. (2008), An empirical survey of individual customer, business firm and financial institution attitudes towards Islamic methods of finance, International Journal of Social Economics, Vol. 35 No. 11, pp. 783-808.

[15]. Haron S, and Azmi S. (2008). Determinants of Islamic and conventional deposits in the Malaysian banking system. Management Finance. Vol. 34(9): pp. 618-643

[16]. Haron, S. and K. Yamirudeng. (2003). Islamic banking in Thailand: Prospects and challenges. International Journal of Islamic Financial Services. Vol. 5 (2): pp. 1-11.

[17]. Haque, A., Osman, J. and Ismail, A. (2009), Factor influences selection of Islamic banking: a study on Malaysian customer preferences, American Journal of Applied Sciences, Vol. 6 No. 5, pp. 922-8.

[18]. Kaynak, E. and Harcar, T. (2004), American consumers' attitudes towards commercial banks, a comparison of local and national bank customers by use of geo-demographic segmentation, International Journal of Bank Marketing, Vol. 23 No. 1, pp. 73-89. 
